\title{
Moodit elvytetyn rebetikan kirjallisuudessa
}

Kreikkalaiset rebetika-muusikot kutsuvat käyttämiään säveljärjestelmiä nimellä dromos. Usein he sanovat dromosin olevan asteikko (klimaka). Muusikoille asteikko on lähinnä teoreettinen apuväline, jota he käyttävät opetus- ja oppimistilanteessa dromosien havainnollistamiseen. On totta, että dromosit voidaan kirjoittaa asteikkomuotoon. Lisäksi osa dromoseista - madzore ja minore - on länsimaisia skaaloja. Enimmäkseen ne ovat kuitenkin nimiltään, rakenteiltaan ja osittain myös toimintaperiaatteiltaan turkkilaisille makameille sukua olevia modaalisia järjestelmiä. ${ }^{2}$ Dromoseja käytetään sekä sävellyksissä että vapaametrisissä taksimi-soitinimprovisaatioissa. Aiemmin ne toimivat myös amane-vokaali-improvisaatioiden pohjana.

1970-luvulla vanha, ennen toista maailmansotaa kukoistanut rebetika herätettiin uudelleen henkiin. Dromoseja voi nykyään tutkia uusissa konteksteissa, jotka ovat modernisaation ja länsimaistumisen tuotteita. ${ }^{3}$ Analyysin kohteeksi on mahdollista valita folkloren sijasta booklore, rebetika-revivalin tuottamat lukuisat dromoseja koskevat kirjalliset esitykset. Tutkimusmateriaali jakaantuu kahteen ryhmään: soitto-oppaisiin ja varsinaisiin dromos-kirjoihin. Tämä artikkeli pyrkii valaisemaan dromos-aihepiirin muutamia keskeisiä kysymyksiä, kuten dromosien olemusta, niiden käyttäytymistä, niiden alkuperää ja keskinäistä sukulaisuutta sekä niiden muuttumista.

Modaalisuuden ja duurimollitonaalisuuden sekoittumisen vuoksi kaikki rebetika-sävellykset eivät ole puhtaasti modaalisia. Jo vuosisadan alussa levytetyissä smyrneiko-lauluissa modaalista A-taitetta saattaa seurata täysin tonaalinen, kolmisointuaihelmia sisältävä B-taite. Vanhaan repertoaariinkin kuului täysin länsimaistyylisiä kappaleita. Tämä on osoitus Istanbulin ja Smyrnan (Izmirin) kreikkalaisväestön musiikin fuusioluonteesta.

1) Tätä kreikkalaisen musiikkikulttuurin tutkimusprojektin osatutkimusta ovat edesauttaneet mm. Ross Daly, prof. Markos Dragoumis, prof. Vesa Kurkela, Martti Leiwo ja Jorgos Simeonidis.

2) Myös bysanttilaisen kirkkolaulun ja kreikkalaisen maaseutumusiikin vaikutus rebetikasävelmiin on kiistämätön (ks. Dragoumis 1975, 21-23).

3) Modernisaatio on järjestelmän tai sen osien satunnainen liukuminen länsimaisen musiikin ja musiikkielämän suuntaan niin, ettei se aiheuta suuria länsimaisista poikkeavien peruspiirteiden muutoksia. Sen sijaan länsimaistuminen on keskeisten länsimaisista poikkeavien puolien korvaantumista länsimaisilla siten, että perinteen perusta usein muuttuu. (Nettl 1985, 20). 
Vahvasti turkkilaisvaikutteista smyrneiko- eli café-tyyliä 1920- ja 1930-luvuilla soittaneet muusikot ovat luultavasti ajatelleet käyttämistään moodeista huomattavan samansuuntaisesti. Monet näistä Turkista Kreikkaan vuoden 1922-23 sodan aikana paenneista muusikoista hallitsivat turkkilaisen taidemusiikin teoriaa ja varsinkin sen käytäntöä. Vähemmän hienostunutta musiikkia soittaneet $\mathrm{Pi}$ reuksen teke-tyylin muusikot eivät sen sijaan olleet saaneet koulutusta. He olivat yhteyksissä smyrneiko-muusikoihin ja saivat heiltä tietoutta, mutta heidän moodivalikoimansa oli suppeampi. 4

1970-luvun alkuun tultaessa aktiivi-iässä olleen muusikkopolven dromos-tietous oli voimakkaasti yksinkertaistunut. Siksi nuoret revival-muusikot joutuivat opiskelemaan sirpaleista dromos-perinnettä vanhojen muusikoiden johdolla tai alkuperäislevytyksiä kuunnellen (ks. Holst 1983, 66; 75; 80). Äänitteiden tärkeys nostaa esiin elvytetyn rebetikan merkittävän modernisaatioulottuvuuden: sekundaarisen muistinvaraisuuden korostumisen. Sekundaarisesti muistinvaraiset perinteet ovat niitä, joissa informaatio kulkee suullisena ja muistinvaraisena muusikolta kuulijalle äänitteiden, radion ja television välityksellä (ks. Kurkela 1991, 8991; Ong 1982, 11).

Useimmat 1980-luvulla ilmestyneet bouzouki- ja dromos-oppaat esittelevät korkeintaan 15 dromosia. Jotkut Ateenassa haastattelemistani muusikoista ${ }^{5}$ tuntevat niitä vähemmän, jotkut taas huomattavastikin enemmän. Yleensä he tunnistavat dromosit intervallirakenteen, stereotyyppisten motiivien ja soinnutuksen perusteella. Soinnut ovat tärkeitä etenkin silloin, kun dromosin kaikkia säveliä ei käytetä. Keskimääräistä suuremmat dromos-määrät johtuvat joko vanhan suullisen perinteen omaksumisesta tai turkkilaisen klassisen teorian sävelhierarkian idean soveltamisesta. Hierarkia-ajattelusssa dromosin nimi ei riipu pelkästään intervallirakenteesta, vaan myös melodian kannalta keskeisten sävelten paikasta. Jotkut muusikot voivat ottaa huomioon myös kahden moodin yhteensulautumisesta syntyneet yhdistelmä-dromosit.

\section{Rebetikan modernisaatio ja länsimaistuminen}

Rebetikan säveljärjestelmiä on tutkittu vähän (ks. Dietrich 1987; Einarsson 1987; $1990 ; 1991)$. Syynä lienee tutkimuskohteen näennäinen hajanaisuus, joka on luonteenomaista suulliselle perinteelle. Rebetikasta on vaikea löytää Lähi-idän kodifioitujen musiikinteorioiden kaltaisia systemaattisia säännöstöjä. Lisäksi muusikot, joiden sanotaan tunteneen dromos-perinteen parhaiten, ovat jo manan majoilla. Perinteen hajanaisuus näkyy nimitysten ja rakenteiden vaihtelevuutena

4) Esimerkiksi Markos Vamvakaris $(1973,271)$ väittää muistelmissaan, että 1930-luvun muusikot olisivat tunteneet set araban -nimisen dromosin. Turkkilainen setaraban on verraten mutkikas yhdistelmämakam, jota ei löydy ainakaan Vamvakarisin tuotannosta.

5) Haastattelut on tehty Ateenassa vuosina 1989-1993. Haastateltaviin kuuluvat Dimitris Anagostopoulos, Stelios Biblis, Jannis Emmanouilidis, Hristos Kalambokis, Vangelis Korakakis, Nikos Kralis ja Hristos Spourdalakis. 
myös kirjallisissa lähteissä. 6

On vaikea selvittää kaikkien dromosien alkuperää johtamalla ne esimerkiksi turkkilaisista makameista. Tämä ei luultavasti ole mahdollistakaan, mutta rakenneyhtäläisyyksiä on enemmän kuin on luultu. Nykyiset dromosit syntyivät, kun monofonisia turkkilaistyylisiä sävelmiä alettiin säestää soinnuin. Tasavireistämisen ja harmonisoinnin jälkeen syntyneen uuden repertoaarin vaikutukset ovat yltäneet myös teoreettisiin asteikkorakenteisiin. Modaalisen harmonian oikut selittävät osan käytännön melodianluonnin ja kirjallisten asteikkoesitysten eroista.

Bruno Nettlin (1986, 362-363) mukaan länsimaisen harmonian vaikutus musiikkikulttuureiden jo olemassa oleviin sävelmiin ja uusiin sävellyksiin kuuluu tärkeimpiin länsimaistumisilmiöihin. Tähän prosessiin liittyy länsimaisia duuri- ja molliasteikkoja muistuttavien skaalojen ja moodien yleistyminen. Ennalta sävelletyn materiaalin asema on korostunut joissain improvisaatiota painottaneissa musiikkikulttuureissa. Samalla nuottikirjoitus on tullut aiempaa tärkeämmäksi. Metriset rakenteet ovat niin ikään vieneet alaa vapaametrisiltä, ja mutkikkaat rytmikaavat ovat yksinkertaistuneet. Kaikki nämä muutokset ovat nähtävissä kreikkalaisen kaupunkimusiikin kehityksessä.

Elvytettyyn rebetikaan on pyritty soveltamaan myös länsimaisia ideoita ja instituutiota. Esimerkiksi länsimaisesta taidemusiikista juontuva koulutusjärjestelmä yleistyi kreikkalaisessa populaarimusiikissa viimeistään 1980-luvulla. Nykyisin aloittelevat soittajat voivat saada tunteja musiikkikouluissa tai oppia bouzoukinsoittoa metodikirjoista joko opettajan johdolla tai yksin. Dimitris Boukouvalas on tämän hetken merkittävin länsimaistyylinen pedagogi. Hänen nuotinnoksensa sisältävät tarkat sormitusohjeet klassisen kitaranotaation tapaa. Tällainen pyrkimys soittotekniikan ja repertoaarin standardointiin ja kodifiointiin on yksi länsimaistumisprosessin ilmentymistä. Markkinoille ilmestyvät säveljärjestelmän kirjalliset esitykset ja niiden teoriat on tarkoitettu nostamaan opettajan, hänen koulunsa ja hänen opettamansa musiikin statusta uudessa kulttuurisessa tilanteessa.

Systematisoituun, kodifioituun ja kirjalliseen teoriaan pyrkivät bouzouki- ja musiikinopettajat ovat tulkinneet dromos-folkloren kaaokseksi, josta on päästävä eroon järjestellyn bookloren avulla. Boukouvalas $(1985,69)$ selittää hajanaisuuden johtuvan suullisen perinteen muuntumisesta sen siirtyessä sukupolvelta toiselle. Hänen mukaansa dromosit ovat lähtöisin antiikin Kreikan moodeista, joista ne ovat siirtyneet bysanttilaiseen kirkkolauluun ja Lähi-idän musiikkiin. Boukouvalas legitimoi asteikkonsa väittämällä niiden perustuvan vanhaan ja yleisesti käytössä olevaan järjestelmään. ${ }^{7}$ (Ibid. 2-3).

6) Samalla dromosilla voi olla useita nimiä. Oppaiden kirjoittajat kutsuvat dromos souzinakia pireotiko minoreksi (Piruksen minore), roumanikosiksi (romanialais-dromos) tai poimenikosiksi (paimen-dromos). Muutamat dromosit ovat saaneet vaihtoehtoisen nimen niitä seuraavien suosittujen sävelmien mukaan. Tunnetuimpia esimerkkejä ovat Dzivaeri ja Tabahaniotiko.

7) Oman kertomansa mukaan Boukouvalas työskenteli Kreikan EMI-levy-yhtiön palveluksessa 1960luvulla. Tällöin hän kiinnostui rebetikasta ja oppi dromoseja $\mathrm{mm}$. bouzoukivirtuoosi Manolis Hiotisilta. 


\section{Asteikko, moodi ja melodia}

Harold S. Powersin $(1980,377)$ mukaan moodi voidaan määritellä joko täsmennetyksi asteikoksi tai yleistetyksi sävelmäksi. Musiikillinen ja kulttuurikonteksti voi sallia molempien määritelmien samanaikaisen käytön. Mikäli asteikon ja sävelmän ajatellaan olevan melodian ennaltamääräämisen ääripisteet, suurin osa niiden välimaastoa kuuluu tavalla tai toisella moodin alueeseen. Moodin ilmeneminen musiikkikappaleessa edellyttää jonkinasteista sävelkorkeuksien hierarkiaa tai esiintymisjärjestystä. Kyseessä on siis enemmän kuin pelkkä skaala. Samalla musiikkikappaleen moodi ei ole niin rajattu, että sitä voisi kutsua tietyksi sävelmäksi. Moodi on aina vähintään melodiatyyppi tai -malli, ei koskaan ennaltamäärätty sävelmä.

Asteikon ja melodian suhde voidaan johtaa oppositiopariin yleinen - erityinen, jonka usein ajatellaan ilmenevän musiikissa teorian ja käytännön vastakohtaisuutena. Kun moodit tulkitaan ensisijaisesti asteikkomaisiksi, niitä käytetään musiikkikokonaisuuksien luokitteluun ideaalityyppeihin. Kun painotetaan modaalisuuden melodisia puolia, moodit nähdään säveltämisen ja improvisoinnin ohjeina ja normeina. (lbid.).

Luokittelun merkitys on ilmeinen. Dromos-kirjallisuudessa asteikot yleensä ryhmitellään 3. asteen perusteella duuri- ja molliluokkiin. Tämä ilmentää länsimaisen duurimollijärjestelmän omaksumista teoreettiseen ajatteluun. Luokitteluun käytetyt asteikkojärjestelmät ovat suljettuja. Niinpä dromos-kirjoittajat ottavat harvoin huomioon kutakin säveljärjestelmää noudattaville melodioille luonteenomaiset sivusävelet ja modulaatiot.

Länsimaisille skaaloille on ominaista, että ne voidaan kuvata täydellisesti oktaavin alueella, jolloin rakenteen ajatellaan kertautuvan oktaaveittain ylös- ja alaspäin. Kreikkalaiset kirjoittajatkin kuvaavat dromos-asteikot symmetrisinä. Monet tekniikkaharjoitukset perustuvat symmetrisoituihin asteikkoihin. Melodiakäytössä dromosien oktaavit voivat kuitenkin poiketa toisistaan aivan kuten turkkilaisissa makameissa. Epäidenttisiä oktaavialoja tapaa etenkin vanhoissa kappaleissa, mutta myös uusissa sävellyksissä.

Hyvä esimerkki oktaavien yhdenmukaistumisesta on dromos sabah (esimerkki 1). Vanhoissa sävelmissä dromos sabah muistuttaa turkkilaista makam sabâa, sillä sen oktaavialat poikkeavat toisistaan. Uudemmissa ne saattavat olla samanlaisia. Dromos sabahin muuttuminen alkoi lievänä jo 1930-luvun Pireuksen rebetikassa. Alkuperäisen alennetun 8 . asteen nouseminen puolisävelaskeleen verran johtuu ilmeisesti siitä, että oktaavin ollessa puhdas soinnutus on helpompaa. ${ }^{8}$ Oktaavialojen symmetrisoituminen johtunee muusikoiden pyrkimyksestä yksinkertaistaa monimutkaista sabahia. Bookloressa tämä pyrkimys symmetriaan on viety huippuunsa. Dromosin perussolu $d-e-f-g b$ on kuitenkin säilynyt muuttumattomana.

8) Spectorin (1970, 248-249) mukaan Egyptissä soitetun maqam rastin oktaavin suuruus ei ole juuri koskaan $1200 \mathrm{c}$, vaan hieman vähemmän. Oktaavin puhtaus ei siis näytä tärkeältä. 
Esimerkki 1. Dromos sabahin vanhasta repertoaarista johdettu ja uusi, kirjallisuudessa esiintyvä asteikkomuoto.

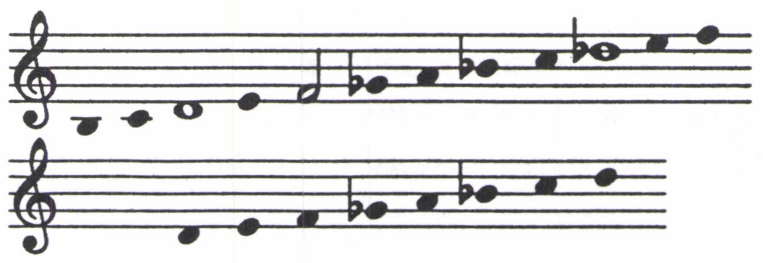

On kyseenalaista, vaikuttavatko teoreettiset, symmetriset skaalat käytännön musisointiin. Vaikka ammattimuusikko soittaisikin opetustarkoituksissa useimmat dromosit symmetrisinä asteikkoina, pyyntö soittaa usean oktaavin sabah-asteikko saa hänet hämilleen. Käytännössä sabah on säilynyt melodiamallina, sävellyssäännöstönä.

Asteikkojen alkuperällä ja niiden luomilla assosiaatioilla saattaa olla vain vähän tekemistä sen musiikin kanssa, johon niitä sovelletaan. Madzore ja minore selitetään dromosiksi, vaikka ne ovat peräisin länsimaisesta musiikista. Duuriasteikon asema on vahva, koska se toimii kaikkien dromos-skaalojen ajatuksellisena esikuvana. Lisäksi duuria säveliltään muistuttava dromos rast selitetään usein teoreettisena asteikkona madzoren kautta. Kuitenkin melodian tasolla nämä dromosit poikkeavat selvästi toisistaan. Vaikuttaa siltä, että muusikot pitävät modaalisuutta kreikkalaisen musiikkikulttuurin perustavana ominaisuutena, koska he laskevat länsimaisen duuri- ja molliasteikon muista poikkeavasta alkuperästä ja tonaalisesta käyttäytymisestä huolimatta dromoseiksi.

Toinen alkuperään ja mielleyhtymiin liittyvä uuden rebetika-aallon piirre on se, että muutamat dromos-oppaiden tekijät pyrkivät esittämään muita kuin suulliseen perinteeseen pohjautuvia dromoseja. He yrittävät siirtää turkkilaisista teoriakirjoista löytämiään asteikkorakenteita kreikkalaiseen kontekstiin, vaikka eivät osaa turkkia eivätkä hallitse turkkilaisen musiikin teoriaa. Tulokset ovat usein hämmästyttäviä; niillä ei ole mitään tekemistä soivan todellisuuden kanssa. Tämä fantisointi voidaan esittää jopa näennäistieteellisessä asussa. IImiön voisi tulkita arvostuksen hakemiseksi dromoseja mutkistamalla ja perinnettä mystifioimalla. Kuvitteelliset asteikot ovat kiinnostava osa uutta booklorea.

\section{Turkkilainen makam rast}

Turkkilainen klassinen musiikki on pohjimmiltaan monofonista, mutta käytännössä sitä esitetään heterofonisesti. Sen pohjana on kaksi järjestelmää: melodiaa ohjaava makam ja rytmiin liittyvä usul. Signell $(1977,16)$ määrittelee makamin sävellyssäännöstöksi, jonka avulla luodaan musiikkikappaleen melodinen aines. Nykyisin Turkissa käytetään noin 70 makamia, joilla kullakin on oma nimensä ja intervallirakenteensa. Makamit erotetaan toisistaan intervallirakenteen, melodian pysähtymispaikkojen järjestyksen, modulaation, stereotyyppisten motiivien sekä 
tessituran avulla. ${ }^{9}$ (Ibid. 149).

Turkkilaisen klassisen musiikin kanonisoidun teorian luojat ovat Rauf Yekta (1871-1935), Suphi Ezgi (1869-1962) ja H. Sadettin Arel (1880-1955). Heidän teoriansa tuntee viisi perusintervallia, jotka ilmaistaan fazlan eli komman ${ }^{10}$ avulla. Ne ovat heikko puoliaskel (4 kommaa), puoliaskel (5 kommaa), heikko kokoaskel (8 kommaa), kokoaskel (9 kommaa) sekä vahva kokoaskel (12 kommaa). (Ibid. 22-23).

Ezgin ja Arelin kehittämä notaatio sisältää kuusi kromaattista merkkiä:

$\begin{array}{llll}\text { nostaa } 1 \text { komman } & \text { laskee } 1 \text { komman } & d \\ \text { nostaa } 4 \text { kommaa } & \$ & \text { laskee } 4 \text { kommaa } & \text { b } \\ \text { nostaa } 5 \text { kommaa } & \$ & \text { laskee } 5 \text { kommaa } & b\end{array}$

Makamien intervallirakenteet syntyvät yhdistelemällä erilaisia tetra- ja pentakordeja. Esimerkiksi makam rastin perusasteikko koostuu rast-pentakordista ja neva-sävelelle $\left(d^{1}\right)$ transponoidusta rast-tetrakordista (esimerkki 2). Makamin oktaavit ovat identtiset. Sen sijaan monissa muissa makameissa on poikkeusoktaaveja.

Esimerkki 2. Rast-pentakordi ja neva-sävelelle ( $\left.d^{1}\right)$ transponoitu rast-tetrakordi.
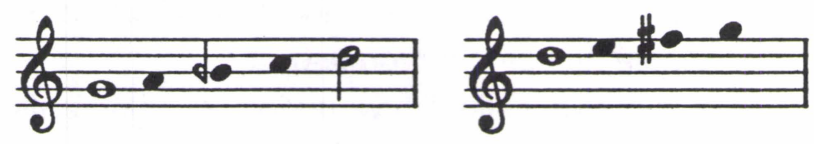

Kutakin makamia noudattavan melodian etenemistä määrää seyir-säännöstö. Seyir sanelee melodian pysähdyspaikat eli makamin akselisävelet. Niistä toonika eli finalis (karar) päättää melodian. Ylätoonikalla (tiz durak) on usein tärkeä asema seyirissä. Sisääntulo (giris) on sävel, jonka ympärillä melodian ensimmäinen säe liikkuu, ja se voi olla toonika, dominantti tai ylätoonika. Dominantti (güçlü) on tärkeä akselisävel sisääntulon ja finaliksen puolivälissä. Se on usein kvintin tai kvartin päässä toonikasta, mutta välimatka voi olla myös terssi. Väliaikaiset pysähdykset (muvakkat kal1slar) eivät tunnu yhtä lopullisilta kuin finalis eivätkä yhtä hallitsevilta kuin dominantti. (Ibid. 48-49).

Funktioltaan erittäin aktiiviset sävelet akselisävelten välissä auttavat määrittämään melodian etenemistä. Niistä tärkeimmät ovat johtosävel (yeden) ja pidätetty kadenssi (asma karar). Johtosävel sijaitsee makamista riippuen koko- tai puolisävelaskeleen toonikan alapuolella. Myös dominantilla voi olla johtosävel.

9) Touma (1978a; 1978b) ja Al Faruqi (1979) ovat epäilleet stereotyyppisten motiivien olemassaoloa kollektiivitraditiossa. Tätä Signelliin kohdistunutta kritiikkiä voi pitää perusteettomana. Käytännön muusikot tunnistavat ja käyttävät makamkohtaisia motiiveja.

10) Kyseessä on ns. arabialainen komma (oktaavin 53-osa, 22.483 c), joka poikkeaa pythagoralaisesta $(23.46 \mathrm{c})$ ja syntonisesta $(21.306 \mathrm{c})$ kommasta. 
Melodian kromaattiset merkit eivät siis välttämättä tarkoita modulaatiota, koska makamien perusasteikoissa on sekä kiinteitä että muuntuvia säveliä. (lbid. 49).

Kunkin makamin seyirillä on melodinen suunta, joka voi olla nouseva, laskeva tai niiden välimuoto. Suunta määräytyy sisääntulosävelen ja finaliksen keskinäisestä suhteesta Nousevaa seyiriä noudattava melodia alkaa toonikan lähistöltä, nousee vähitellen dominanttiin ja palaa lopulta toonikaan. Laskeva melodinen suunta ohjaa melodian alkamaan ylätoonikasta tai sen lähistöltä, laskeutumaan melodiakulun puolivälissä dominanttiin ja kadensoitumaan oktaavia sisääntulon alapuolella. Nouseva-laskevan seyirin melodia alkaa dominantin tienoilta, liikkuu sisääntulon ylä- ja alapuolella, kunnes pysähtyy sisääntuloon. Lopuksi melodia päättyy toonikaan. Seyirin suunta voidaan ilmaista asteikon yläpuolelle piirretyn nuolen avulla. Useilla makameilla voi olla sama asteikko, finalis ja dominantti, mutta eri melodiset suunnat. Niinpä makam rastin ja sen lähisukulaisen makam mahurin ainut käytännön ero on seyir, joka on rastissa nouseva, mutta mahurissa laskeva. (lbid. 50-51). ${ }^{11}$

Makam rastin (esimerkki 3) toonika- eli finalissävel on $\mathrm{g}^{1}$ (rast). ${ }^{12}$ Samalla se on sisääntulosävel. Dominantti on viides aste. Alaspäisissä melodiakuluissa f $^{2}$ (eviç) saattaa tasaantua $\mathrm{f}^{2}$-säveleksi (acem). Vastaava ilmiö tapahtuu useissa muissakin makameissa (ks. ibid. 43). Makamille voidaan antaa väriä lisäämällä siihen hetkeksi jokin vieras sävel. Makam rast -sävelmissä on yleinen runkosäveliin varsinaisesti kuulumaton, makam nihaventista lainattu kürdi-sävel ( $\mathrm{hb}^{\mathrm{b}}$ ), joka korvaa kolmannen asteen eli segâhin ( ${ }^{\mathrm{d}}{ }^{1}$ ). Makamin johtosävel on $\mathrm{f \#}^{1}$ (irak). Seyir on nouseva, joten sisääntulo on toonikasävel.

Esimerkki 3. Makam rastin asteikko teoreettisella sävelkorkeudellaan ja transponoituna d-pohjaiseksi. ${ }^{13}$

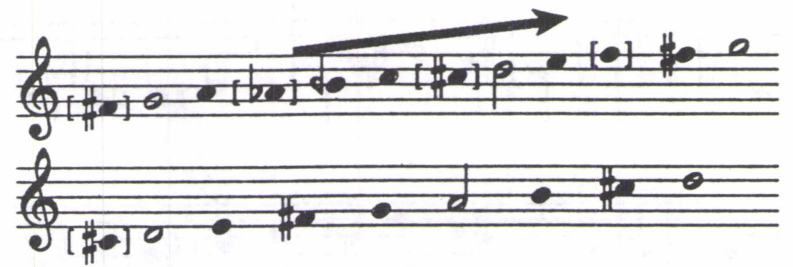

Kreikkalainen dromos rast ja sen sukulaiset

Rast, madzore ja houzam ovat lähekkäisiä dromoseja, joita rebetika-muusikot eivät aina kykene erottamaan toisistaan. Madzore voidaan määritellä länsimaisittain tonaalisesti käytetyksi, yksinkertaistetuksi rastiksi, jossa kolmas aste ei esiinny alennettuna. Dromos rast on asteikoltaan lähes sama kuin sen turkkilainen vastine.

11) Suosituimmat makamit voivat noudattaa kahta vaihtoehtoista melodista suuntaa (ks. Özkan 1984, $134 ; 140 ; 146)$. Turkkilaisen puoliklassisessa fas1l-musiikissa intonaatio, makamien melodiset suunnat sekä soittotyyli eivät noudata klassista käytäntöä (Signell 1977, 11-12). Etenkin vanhempaan rebetikaan on lainattu runsaasti melodioita tästä mustalaisten esittämästä musiikista.

12) Turkkilaisista sävelnimistä ks. Signell 1977, 26-29.

13) Lähes kaikki nuottiesimerkit on transponoitu vertailun helpottamiseksi d-pohjaisiksi. D rebetikan perussävellajina juontuu bouzoukin yleisimpään viritykseen dd'-aa-d'd' (vrt. Einarsson 1987). 
Koska dromos rast muistuttaa dromos madzorea ja dromos houzamia, oppaiden laatijat eivät ole selvillä sen rakenteestä (esimerkki 4). Boukouvalasin (1985, $84)$ ja Loukareasin $(1985,14)$ mielestä dromos rast ja länsimainen duuriasteikko (madzore) ovat identtisiä. Kuitenkin heidän opetustarkoituksiin nuotintamansa rast-taksimit (Boukouvalas 1987, 8-9; Loukareas 1985, 14) sisältävät madzoreen kuulumattomia sivusäveliä. Boukouvalas alentaa tilapäisesti 3. ja 7. asteen, joten hän pääsee lähelle turkkilaista makam rastia. Loukareas tekee saman. Lisäksi hän käyttää tilapäisesti korotettua 4. astetta, joka on dominantin johtosävel. Dromos rastin huojuva 3 . aste johtunee makam rastiin lainatusta kürdi-sävelestä.

Esimerkki 4. Dromos rastin variantteja.
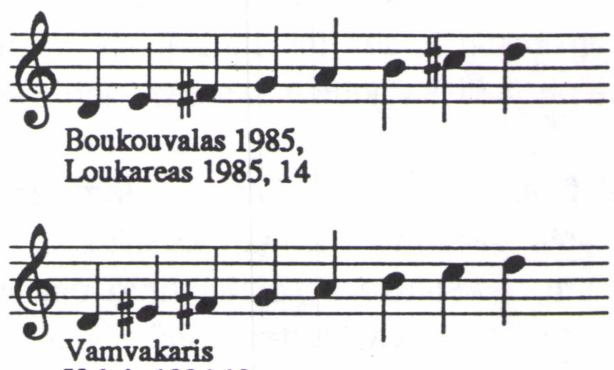

Valvis 1984,12
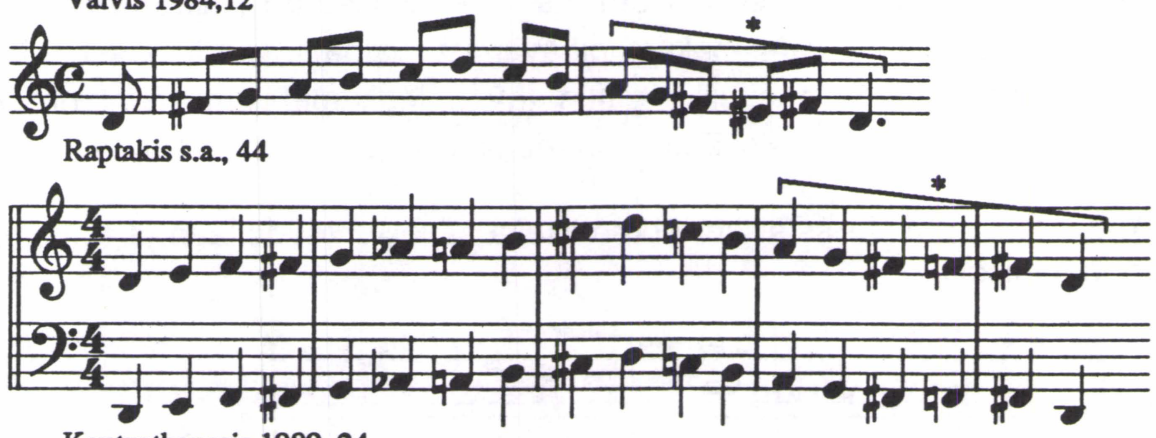

Koutsothanasis 1989, 24

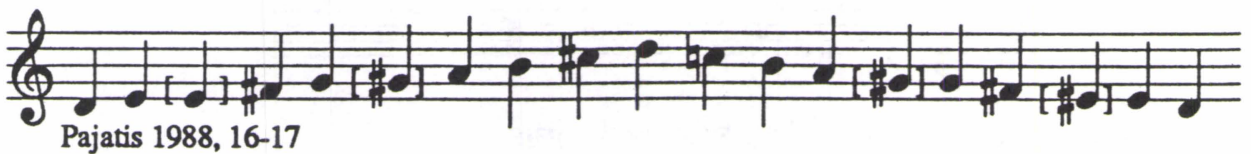

Pajatis 1988, 16-17

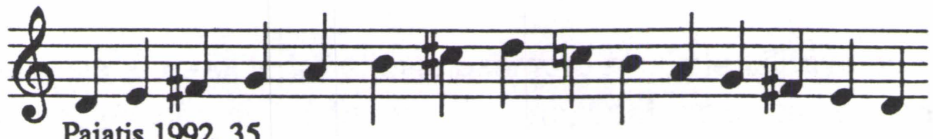

Pajatis 1992, 35

Mavromoustakisin $(1984,37)$, Konstandinidoun $(1987,136)$ ja Koutisin $(1985,50)$ näkemyksen mukaan dromos rast on kuin madzore, jonka 6 . aste on ylennetty. Markos Vamvakarisin ja häntä lainaavan Valvisin $(1984,12)$ rast on puolestaan rakenne, joka yleensä tunnetaan nimellä dromos houzam. Ennen kuolemaansa Vamvakaris luetteli 11 dromosin nimet ja skaalat häntä haastatelleelle lehtimiehelle Jorgos Kondojannisille. Valvis on ainoa Vamvakarisin luettelon omaksunut 
kirjoittaja. Raptakis (s.a.) on joukon ainut, joka esittää dromosinsa ennemmin melodioina kuin asteikkoina. Myös hänen rastinsa tunnetaan yleensä nimellä houzam.

Koutsothanasis $(1989,24)$ esittää dromos rastinsa nousevan ja laskevan muodon lähes turkkilaisittain, mutta liittää loppuun dromos houzamiin kuuluvan stereotyyppisen motiivin (*). Koutsothanasisin esimerkkisävelmässä 2. aste on jatkuvasti ylennetty, joten melodia on itse asiassa dromos houzamissa. Käytännössä rastin ja houzamin ero jää epäselväksi. Pajatis (1988, 16-17) kirjoittaa dromos rastinsa runko- ja sivusävelet samalla tapaa kuin turkkilainen tekisi. Kirjansa myöhemmässä, laajennetussa laitoksessa (Pajatis 1992, 35) hän muuttaa mielipidettään madzoren suuntaan.

Kaksi kirjoittajaa käsittelee myös dromos rastiin kuuluvaa stereotyyppistä motiivia. Loukareas $(1985,37)$ ja häntä lähdettä mainitsematta lainaava Pajatis (1992, 36-37) selittävät rastissa usein esiintyvän kromaattisen motiivin olevan nimeltään dromos rast mahour eli dromos rast adzem (esimerkki 5). Turkkilainen teoria ei tunne tällaista makamia.

Esimerkki 5. Loukareasin ja Pajatisin dromos rast mahour eli dromos rast adzem.

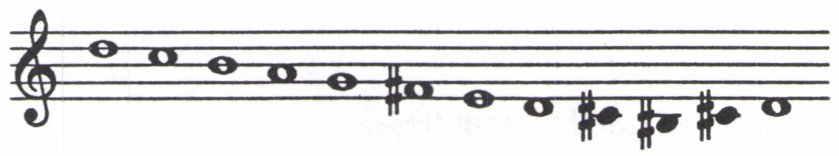

Mikäli Loukareasilla on jokin muu lähde kuin oma mielikuvitus, nimien alkuperää voi etsiä turkkilaisesta musiikkisanastosta. Rast mahur olisi turkkilaisen teorian mukaan yhdistelmämakam, joka koostuisi asteikoiltaan samoilta mutta seyireiltään vastakkaista makameista, mikä on mahdotonta. Nimitys saattaa olla peräisin joltain vanhalta amane-levyltä, jonka etiketti ilmaisee sekä päämakamin (rast) että modulaation (mahur) (ks. esim. AF 90: B1, Rast mahour). Sanapari rast adzem voisi perustua olemassa olevaan turkkilaiseen ilmaisuun acemli rast. Se tarkoittaa makam rastin alaspäin johtavaa muotoa, jossa seitsemäs aste on alennettu (ks. Özkan 1984, 115). Kromaattiseen motiiviin se ei kuitenkaan viittaa, sillä turkkilaisessa klassisessa perinteessä ei käytetä sellaista. Luultavasti Loukareas on halunnut antaa rebetikassa usein toistuvalle motiiville jonkin nimen, joten hän on keksinyt sen itse.

Kromaattisen motiivin todennäköisin alkuperä on dromos rastin asteikossa itsessään. Motiivissa yhdistyy asteikon alas- ja ylöspäinen muoto. Se on siirtynyt dromos rastista myös muihin yhteyksiin.

Loppujen lopuksi kahta lukuunottamatta kaikki Kreikassa painetut dromos rast-asteikot perustuvat makam rastin runko- ja sivusäveliin. Esimerkissä 6 näkyy useita dromos rastin piirteitä. 
Esimerkki 6. Markos Vamvakarisin hasapiko-instrumentaalin Stou Markou to koutouki ensimmäinen taite (EMI 1700761; A5). Nuotinnos RPP.

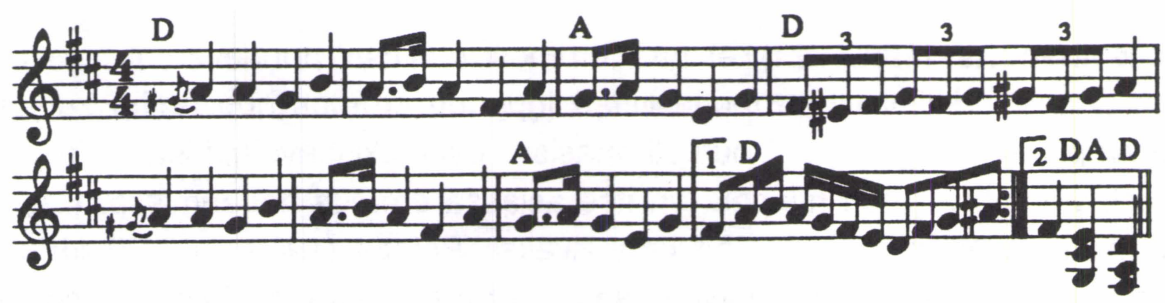

Dromos houzamin synty

Monet revival-muusikot eivät osaa selittää myöskään dromos rastin ja dromos houzamin välistä eroa (ks. Einarsson 1990, alaviite 4). Houzam on ilmeisen ongelmallinen dromos, eikä sen rakenteesta ei vallitse yksimielisyyttä kirjallisuudessakaan (esimerkki 7). Boukouvalas $(1985,85)$ selittää sillä olevan kolme eri muotoa. Hänen lisäkseen Mavromoustakis $(1984,37)$, Koutis $(1985,50)$ ja Pajatis $(1992,38)$ esittävät niistä ensimmäisen, joka on 2. asteeltaan korotettu duuriasteikko. Boukouvalasin toisessa houzamissa 2. asteen korotuksen lisäksi 7. aste on alennettu. Hänen parhaana pitämänsä houzam on näiden kahden muodon yhdistelmä.

Esimerkki 7. Dromos houzamin variantteja.
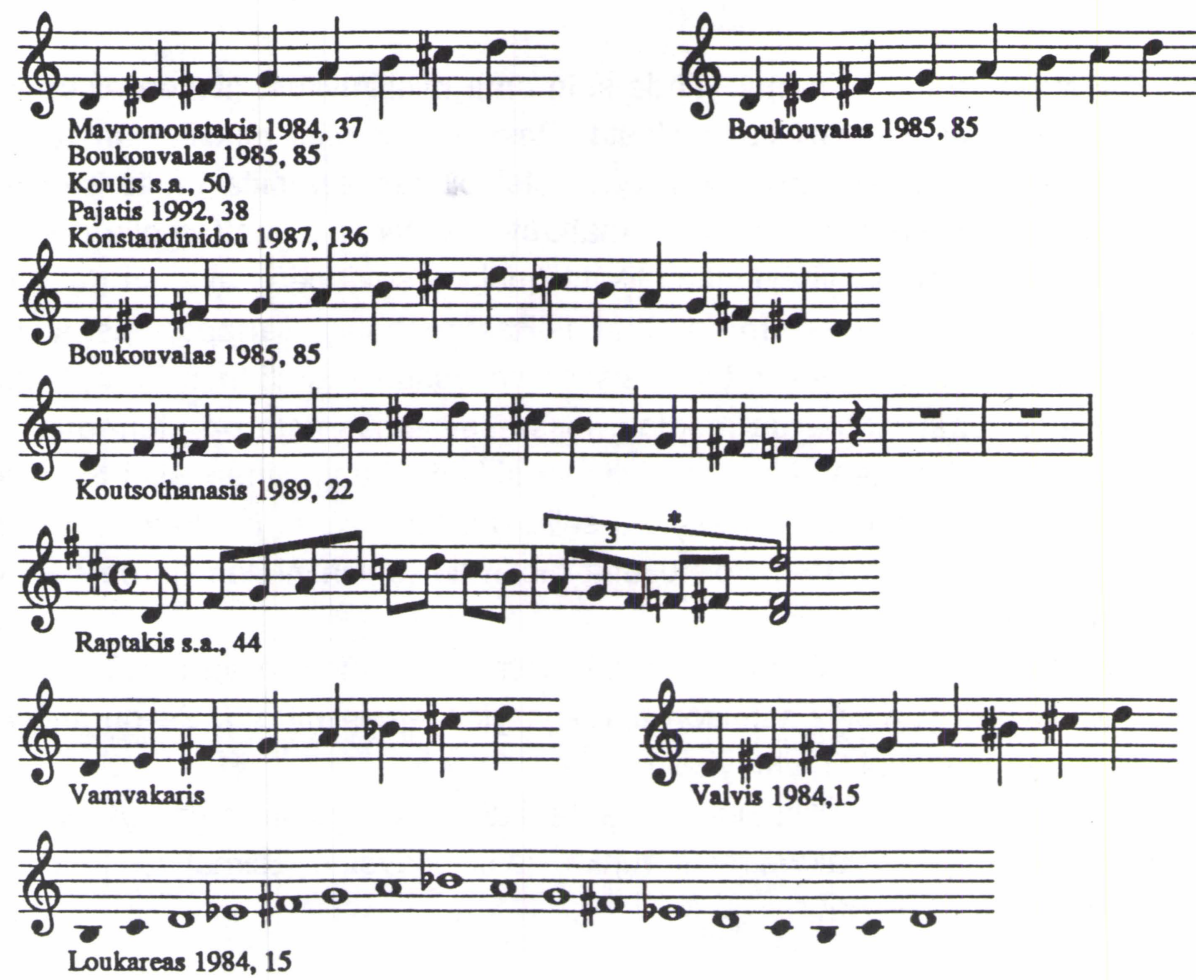
Koutsothanasisin $(1989,22)$ houzam on kuin Boukouvalasin ensimmäinen variantti, mutta siihen liittyy houzamille tyypillinen kadenssimotiivi $\left(^{*}\right)$. Esimerkkisävelmä käyttäytyy kuin Boukouvalasin kolmas variantti, sillä 7. aste on vuoroin ylennetty ja vuoroin palautettu. Raptakis (s.a., 44) esittää houzaminsakin melodiana. Esimerkki on käytännössä sama kuin kirjoittajan dromos rast. Se muistuttaa säveliltään Boukouvalasin toista varianttia, mutta siihen kuuluu houzam-kadenssimotiivi (*).

Vamvakarisin houzam on duuriasteikko, jonka 6. aste on alennettu. Valvis $(1984,11)$ esittää sen, mutta arvelee toisaalla (ibid. 15) sen olevan väärän. Hänen lopullinen houzaminsa on duuriasteikko, jonka 2. ja 6. aste on ylennetty. Kirjoittaja kutsuu houzamia vanhaksi bysanttilaiseksi dromosiksi, jota käytetään amane-improvisaatioissa ja Itä-Aigeian saarten musiikissa.

Ensimmäisessä kirjassaan Pajatis $(1987,11)$ esittää houzamin samalla tavoin kuin Vamvakaris, mutta kirjoittajan laatiman soinnutuksen pohjana oleva asteikko on sama kuin Mavromoustakisin variantissa. Pajatisilla (ibid. 14) on toinen täysin samanlainen asteikko nimellä segah. Kirjoittajan kanta ei selviä edes kirjan lopusta, sillä kaksi kappaleluettelon kolmesta houzam-sävelmästä noudattaa dromos segahia ${ }^{14}$. Myöhemmin Pajatis $(1992,38)$ esitti houzamin samalla tavoin kuin Mavromoustakis. Samalla hän nimesi entisen houzaminsa dromos tabahaniotikosiksi (ibid. 75).

Loukareas $(1985,15)$ väittää, että dromos houzam on sama kuin bysanttilaisen kirkkolaulun toinen ihos. Hän selittää lopullisen finaliksen olevan $d$ ja väliaikaisen finaliksen $\mathrm{h}$. Asteikko näyttää vaillinaiselta dromos hidzazilta, mutta itse asiassa se olisi kuin turkkilainen makam hüzzam, mikäli finalis määriteltäisiin $h$ säveleksi. Kreikassa tämä rakenne tunnetaan yleensä nimellä dromos segah.

Ilmeisesti Loukareas on laatinut asteikon kirjansa turkkilaisen makam hüzzam -esimerkin pohjalta, joka on Sevki Beyn säveltämä (ks. ibid. 153). Koska hüzzam on nouseva-laskeva makam, sen dominantti eli 3. aste korostuu. Kirjaan osittain painetun sävellyksen ensimmäisen taitteen kertaus päättyy dominantille, joten Loukareas on päätellyt sen olevan finalis (esimerkki 8). ${ }^{15}$ Koska ylätoonika on sävellyksen kolmannen taitteen eli moduloivan meyan-osan alussa alennettu, hän yleistää sen kuuluvan hüzzamiin eli houzamiin. Loukareas ei tunnu ymmärtävän melodisen suunnan periaatetta.

Kirjallisia lähteitä ja levytettyjä sävelmiä vertailemalla selviää, että on olemassa kaksi toisistaan hieman poikkeavaa dromos houzamia. Houzam A:n 7. aste on suuri septimi, houzam B:n taas pieni (esimerkki 9). Nämä molemmat rakenteet juontuvat turkkilaiseen makam segâhiin, jolla on kaksi muotoa. Ensimmäisen segâhin alaosan muodostaa täydellinen segâh-pentakordi hd1 $-c^{2}-$ $d^{2}-e^{d 2}-f \#^{2}$. Toisen alaosa on epätäydellinen segâh-pentakordi $h^{d 1}-c^{2}-d^{2}-$

14) Pajatisin houzam-sävelmät ovat 'Irthe o heimonas (säv. Panajotis Toundas), 'Otan kapnizei o loulas (säv. Jorgos Mitsakis) sekä Kaimo mes' tin kardhoula (säv. Jorgos Rovertakis).

15) Loukareas $(1985,152)$ on käyttänyt vastaavanlaista päättelyä luodessaan makam segah -sävellyksen pohjalta dromos sengiahin (ibid. 15) ja makam hüseyni -sävellyksen (ibid. 150) pohjalta dromos houseinin (ibid. 15). 
$e^{d 2}-f^{2}$. Asteikkojen ylärakenteet ja niiden akselisävelet ovat niin ikään erilaiset. Näiden dromosien ja makamien sukulaisuussuhteet eivät näy ensisilmäyksellä. Rakenteiden näennäinen erilaisuus johtuu turkkilaiselle musiikille vieraasta elementistä eli soinnutuksesta.

Esimerkki 8. Osa Sevki Beyn sävellyksestä makam hüzzamissa (Loukareas 1985, 153).

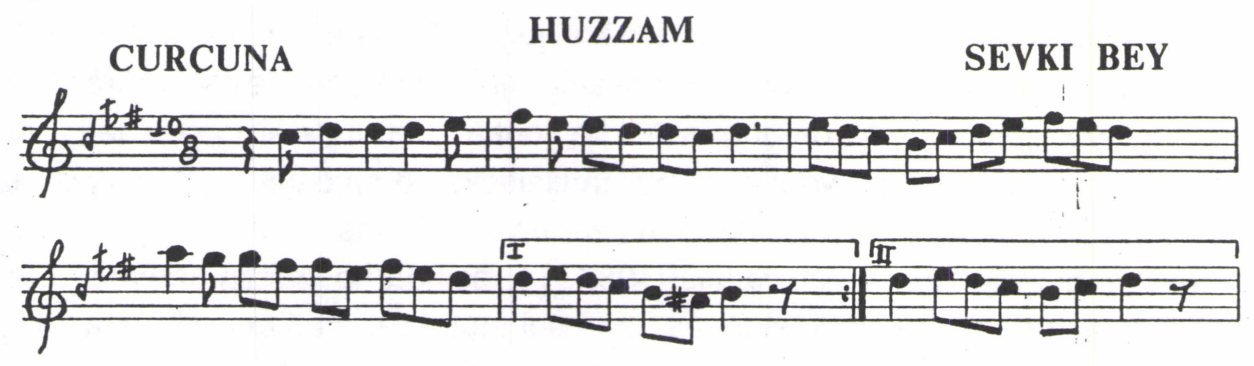

Esimerkki 9. Makam segâhin kaksi muotoa teoreettiselta sävelkorkeudelta (ylärivi) ja dromos houzam A sekä dromos houzam B.
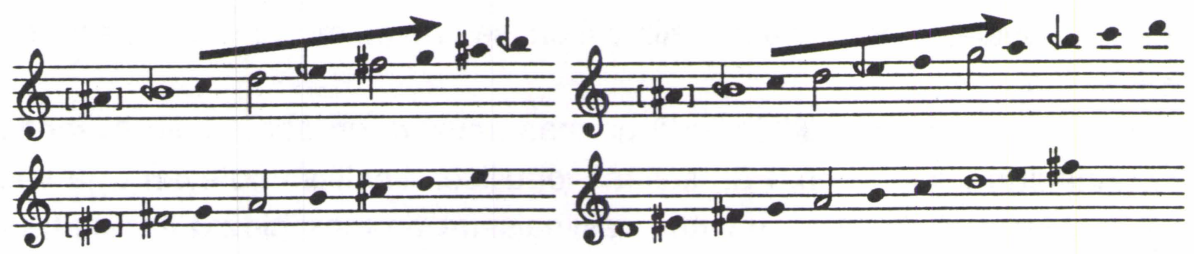

Normaalimuotoisen makam segâhin muuttuminen dromos houzam A:ksi alkoi, kun tätä makamia noudattavia sävelmiä alettiin säestää soinnuin. Makamia ei voi soinnuttaa siten, että soinnut pohjautuisivat akselisäveliin eli toonikaan ja dominanttiin (3. aste), koska niiden funktio olisi sama. Sointuaste iv $(\mathrm{Hm})$ sopisi funktionaaliseen sointuajatteluun, mutta tärkeää v astetta ei voi käyttää, koska se on vähennetty mollisointu (esimerkki 10, ylärivi).

Esimerkki 10. Dromos segâhin kahden muodon teoreettinen (yllä) ja käytäntönä oleva soinnutus.
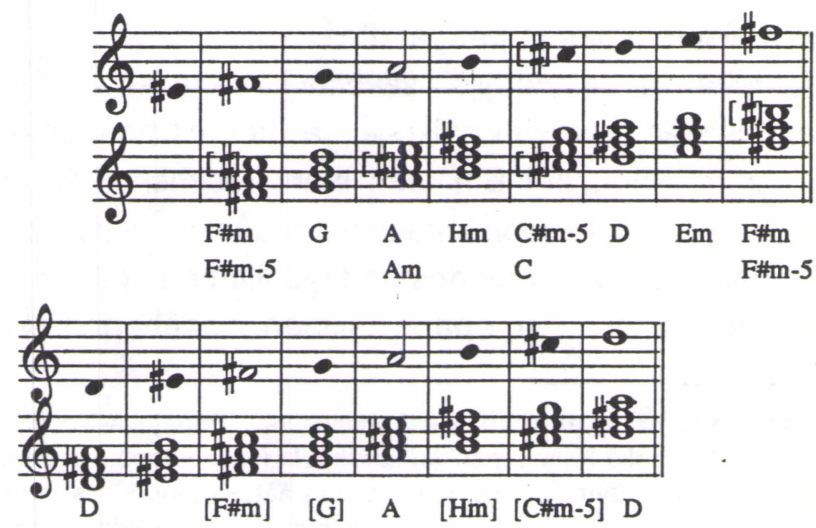
Kreikkalaiset muusikot ovat ratkaisseet soinnutusongelman siirtämällä I asteen sointu suurta terssiä makamin toonikaa alemmaksi (esimerkki 10, alarivi). Tämä on mahdollista, koska dromos houzam A:n asteikko muistuttaa dromos rastia ja jopa madzorea, mikäli se aloitetaan 6. asteelta. Tämän soinnutusidean siemen on turkkilaisessa musiikissa. Makam segâh ja makam rast ovat lähisukulaisia (ks. Signell 1977, 128). Makam rastin asteikon alkupää sisältää osan makam segâhin asteikkoa (esimerkki 11). Sukulaisuus ilmenee myös käytännössä: rast-sävel $\left(g^{1}\right)$ on yksi yleisimmistä turkkilaisten muusikoiden makam segâhissa käyttämistä bordunaäänistä.

Esimerkki 11. Makam rastin ja makam segâhin keskinäinen suhde.

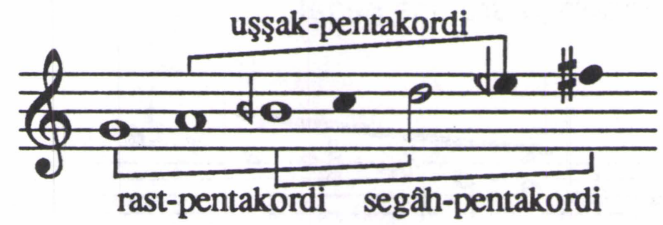

Kun perussointu siirretään suuren terssin dromosin toonikaa alemmaksi, toonika jää soinnun terssiin, dominantti taas kvinttiin. Uusi soinnutus mahdollistaa funktionaalisen sointusuhteen I-V käytön. ${ }^{16}$ Sointujen lisäämisen vuoksi makam segâhista on muovautunut duuripohjainen dromos houzam $A$, vaikka makamin kolmas aste viittaisi molliin. Dromosin erikoisuus on finaliksen sijainti samassa paikassa kuin alkuperäisessä makamissa, siis uuden I asteen soinnun terssissä (esimerkki 12).

Esimerkki 12. Vangelis Papazogloun sävellyksen Lahanadhes alkuosa vuodelta 1934. (ACBA 1132/33; A1). Nuotinnos RPP.

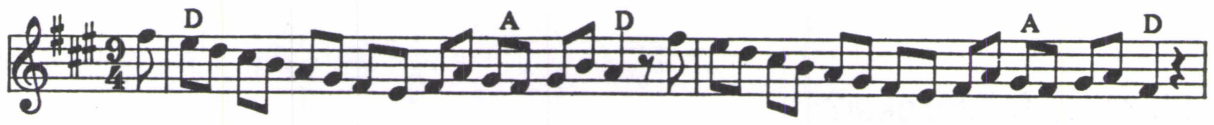

Dromos houzam B:n soinnutuksen asteikkosävelten pohjalta tekee mahdottomaksi jo se, että i-aste olisi vähennetty molli. Siksi perussoinnun siirtäminen suurta terssiä alemmas on luonnollinen ratkaisu. Skaalapohjainen $v$ aste olisi molli, mikä estää funktionaaliseen I-V-sointusuhteiseen pääsemisen. Ongelman ratkai-su on se, että $v$ aste muutetaan duuriksi ja sitä käytetään mahdollisimman vähän.

Soinnutus on muuttanut merkittävästi houzam B:n rakennetta. Sitä noudattavat melodiat kadensoituvat uuden I asteen soinnun vetäminä alkuperäistä finalista suuren terssin alemmaksi (esimerkki 13). Turkkilaisen makam segâhin pohjalta on syntynyt uusi modaalinen rakenne.

16) Heinrich Schenkerin mielestä kaiken hyvän musiikin Ursatz on I-V-I (ks. Middleton 1990, 192195). 
Esimerkki 13. Osa Markos Vamvakarisin sävellystä Ithela namoun Iraklis (Minos 148; A2). Nuotinnos RPP.

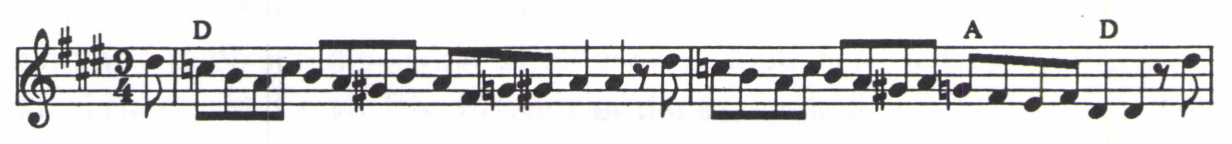

Soinnutus on muuttanut vastaavasti makam hüzzamin dromos segâhiksi. Dromosin perussointu on samasta syystä suuren terssin alkuperäisen makam-asteikon finalista alempana. Tästäkin dromosista on tullut duuripohjainen.

Esimerkki 14. Makam hüzzam ja dromos segâh.

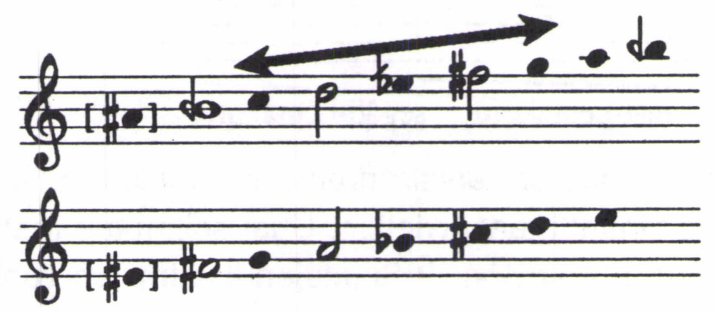

Monet rebetika-muusikot ja varsinkin bouzouki-oppaiden kirjoittajat tajuavat perussoinnun perussävelen aina dromosin finalikseksi, vaikka todellisuudessa finalis voi olla suurta terssiä ylempänä. Kirjoittajilla ei ole keinoja erottaa toisistaan sisääntulo- ja finalissäveliä, koska he tulkitsevat dromosit asteikoiksi. Finaliksen siirtyminen on modaalisuuden ja duurimollitonaalisuuden fuusion kiinnostavimpia lopputuloksia rebetikassa.

\section{Bookloresta folkloreksi?}

Bouzouki-oppaat ja dromos-kirjat saivat merkitystä vasta 1980-luvulla, sillä aiemmin perinne kulki muusikolta toiselle suullisena folklorena tai sekundaarisesti muistinvaraisena levytysten kautta. Itse asiassa vasta 1980-luvun puolivälissä kreikkalaisen musiikkikulttuurin länsimaistuminen saavutti vaiheen, jossa rebetikalle alettiin luoda musiikinteoriaa. 1990-luvulla hajanainen folklore pyritään muuntamaan yhtenäiseksi bookloreksi.

Uuden bookloren vaikutus käytännön musisointiin on jäänyt toistaiseksi vähäiseksi. Yksi tekijä on moniendromos-kirjojen heikko saatavuus. ${ }^{17}$ Lisäksi kirjalliset lähteet ovat liian epäloogisia, jotta lukijat pystyisivät tulkitsemaan niitä samalla tavoin. Kreikasta puuttuu teorian systematisointiin kykenevä kiistämätön auktoriteetti, Hellaan Ilmari Krohn, jonka ajatukset kaikki omaksuisivat mukisematta.

17) Kreikkalaisten kirjojen jakeluverkosto ei ole tehokas. Usein tiettyä kirjaa voi ostaa ainoastaan kustantajan omistamasta kirjakaupasta. 
Loppujen lopuksi: olisiko kirjallinen dromos-teoria edes tarpeellinen? Ammattimuusikot osaavat improvisoida useimpiin dromoseihin ilman teoriaakin. Vanhoille äänitteille säilötty ja jatkuvasti rebetika-paikoissa soitettu repertoaari tarjoaa viljalti käytännön esimerkkejä dromosien käyttäytymisestä. Ainut suuri ongelma on yhteisten nimitysten puuttuminen. Kollektiivitraditio on sittenkin elossa ja voi kohtalaisen hyvin.

\section{Kirjallisuus}

\section{Primaarilähteet}

Boukouvalas, Dimitris I: 1985 Bouzouki i tehniki tou kai i dhidhaskali tis me eidhiko systima simeiografias. Ousak. Tomos dhefteros. Athinai.

- 1987 Taksimia se olous tous dhromous jia bouzouki me eidhiko sistima simeiografias. Taximia for Bouzouki. Athinai.

Konstandinidou, Maria: 1987 Koinoniolojiki Istoria tou Rembetikou. Barbounakis. Thessaloniki.

Koutis, Dimitris J: 1985 Methodhos jia trihordho bouzouki kai baglama. Method for the three string Bouzouki and Baglama. Nakas. Athina.

Koutsothanasis, Vasilis: 1989 Laikoi dromoi kai avtoshedhiasmoi "taksimia". Athina.

Loukareas, Takis P: 1985 "Laikoi dhromoi" Proto antholojio. Ekdhoseis "Neanes". Athina.

Mavromoustakis, A: 1984 Praktiki methodhos ja baglama kai eksahordho bouzouki. Ekdhosis Doremi. Thessaloniki.

Pajatis, Haralambos: 1987 Oi laikoi dhromoi. Ekdhoseis Fagotto. Athina. - 1992 Laikoi dhromoi. Ekdhosi veltiomeni. Ekdhoseis Fagotto. Athina.

Raptakis, Kleon: s.a. Vasiki, Praktiki kai mousiki methodhos tou Bouzoukiu. G. Kahramanis mousikos ekdhotikos oikos. Athinai.

Valvis, J: 1984900 akombaniamenda bouzoukiou. Ekdhoseis Panistas. Athina.

Sekundaarilähteet

Dietrich, Eberhard: 1987 Das Rebetiko. Eine Studie zur städtischen Musik Griechenlands. Beiträge zur Ethnomusikologie 17. Verlag der Musikaliehandlung Karl Dieter Wagner. Hamburg.

Dragoumis, Markos: 1975 The Music of the Rebetes. Songs from the Old Greek Underworld. K. Butterworth et al. (eds.), 16-25. Athens.

Einarsson, Mats: 1987 Grekisk rebetika. En översiktlig beskrivning av rebetikakulturen och stilistiska iakttagelser av musiken. 60-poengsuppsats vid Musikvetenskapliga Institutionen vid Stockholms Universitet.

- 1990 Taxími - improvisation på grekiska. Om den instrumentala improvisationens miljö och praxis på grekiska restauranger och nattklubbar i Stockholm. Owe Ronström (ed.), Musik och Kultur, Studentlitteratur. Lund.

- 1991 Some aspects of form as an intersubjective framework in instrumental improvisations (taximia) in Greek bouzouki music. Proceedings of the Second British-Swedish Conference on Musicology. Ethnomusicology. Cambridge, 510 August 1989, Ann Buckley et al. (eds.), 181-195. Skrifter från Musikvetenskapliga institutionen, Göteborgs universitet, $\mathrm{nr} 26$. Musikmuseets skrifter 21. Göteborg. 
Pennanen

al Faruqi, Lois Ibsen: 1979 Signell, Karl L. Makam: Modal Practice in Turkish Art Music. Yearbook of the International Folk Music Council 1979, 146-148.

Holst, Gail: 1983 Road to Rembetika. Music of a Greek Sub-culture. Songs of Love, Sorrow and Hashish. Third edition. Denise Harvey \& Co. Athens.

Kurkela, Vesa: 1991 Etnomusikologian historiattomuus ja nykyajan haasteet. Kansanmusiikin tutkimus. Metodologian opas, Pirkko Moisala (toim.), 86-101. Sibelius-Akatemian julkaisuja 4. Vapk-kustannus, Helsinki.

Middleton, Richard: 1990 Studying Popular Music. Open University Press. BuckinghamBristol.

Nettl, Bruno: 1985 The Western Impact on World Music: Change, Adaptation and Survive. Schirmer Books. New York-London.

- 1986 World Music in the Twentieth Century: A Survey of Research on Western Influence. Acta Musicologica Vol. LVIII 1986: Fasc II. Juli-December, 360-373.

Ong, Walter J: 1982 Orality and Literacy. The Technologizing of the World. Methuen. London and New York.

Powers, Harold S: 1980 Mode. The New Grove Dictionary of Music and Musicians 12, Stanley Sadie (ed.), 376-450. Macmillan. London-Washington-Hong Kong.

Signell, Karl L: 1977 Makam. Modal Practice in Turkish Art Music. Asian Music Publications. Series D, Number 4. Washington.

Spector, Johanna: 1970 Classical 'Ud Music in Egypt with Special Reference to Maqamat. Ethnomusicology Vol. XIV Nr 2, May 1970, 243-257.

Touma, Habib Hassan: 1978a Signell, Karl L., Makam: Modal Practice in Turkish Art Music. World of Music 1:1978, 117-118.

- 1978b Signell, Karl L. Makam: Modal Practice in Turkish Art Music.

Ethnomusicology, Vol. XXII Nr 2, May 1978, 359-362.

Vamvakaris, Markos: 1973 Avtoviografia. Angela Kail (ed.). Athina.

Özkan, Ismail Hakki: 1984 Türk musikisi nazariyati ve usulleri. Kudüm velveleri. Ötüken Nesriyat. Istanbul.

Äänitteet

ACBA 1132/33 Vangelis Papazoglou. To Smyrneiko tragoudhi stin Elladha meta to 1922. $198 ?$.

AF 90 Avthentika Rembetika tis Amerikis No 4. Ta Fthisika. 1988.

EMI 1700761 Oi Dheksiotehnes No 2. 14 organika kommata ja bouzouki solo. 198 ?.

Minos MSM 148 Markos Vamvakaris, Afieiroma ston Markou. $197 ?$. 